\title{
Chapter 1 \\ Creating Experiences in Cultural Tourism: From Sightseeing to Engaged Emotional Action
}

\author{
Daniela Angelina Jelinčić
}

Culture has often been used as a means for city branding (Jelinčić, Žuvela \& Polić, 2012, p. 11) as well as for urban regeneration (Jelinčić, 2011, p. 61), which has eventually had impact on increasing the number of visitors and tourism development in general. Still, due to the growing diversification of the tourism market and the ever more requiring needs of the cultural tourist, today's cultural tourism supply needs to rely on more than just a brand. It is not any more about passive sightseeing and introduction of tourists to a destination's cultural resources, it is about letting them experience the local identity and participate in the local culture. It is about seeing the destination's resources through a local lens and becoming a local during the holiday period.

The rise of the experience economy in the two last decades has come in very handy for the tourism industry. Tourism is a fertile ground for holiday experiences - which need to be differentiated from the daily routine. Still, along with the constant increase in the number of tourists to certain destinations, experiences are often not pleasurable for the visitors. In order to avoid unpleasant experiences in tourism and to offer memorable 
ones, this chapter introduces the reader to the basic principles of experience creation as seen through the lens of neuroscience and psychology as theoretical grounds. Their further elaboration focuses on the stimulation of senses and eventual emotional response to be achieved in the visitor.

\section{The Link between Experience Economy, Culture and Tourism}

Experience economy originates from the business field and is especially applied in marketing. Alvin Toffler first used it to predict the future economic developments which would depend on the "design of new goods and the process of coating them with stronger, brighter, more emotionpacked psychological connotations" (Toffler, 1970, p. 233). Similarly, years later, Holbrook and Hirschman (1982) wrote about it as a phenomenon directed toward the pursuit of fantasies, feelings and fun. Although the beginnings of experience economy date back to the 1970s, the way we see it today is firmly grounded in the work of the fathers of experience economy - B. Joseph Pine II and James Gilmore. They see experience economy as providing memorable events for their customers, whereas the memory itself becomes the product, the experience. Thus, the experience itself represents an added value which may even lead to a transformation which businesses can charge (1998). Simply put, experience economy entails "economic activities related to peoples' experiences" (Sundbo \& Sørensen, 2013, p. 1). The common feature offered in the mentioned authors' views is seen in the connection between emotional experiences and products/services.

Creativity and experiences are generally seen as features immanent in the cultural sector (see Jelinčić \& Senkić, 2017). Works of art are produced by applying creativity; creativity is usually triggered by an intrinsic emotional stimulus which results in a concrete output such as an artwork and has the potential to stir emotions also in its consumer. "Arts and culture are sectors which inherently deal with emotions" (Jelinčić \& Senkić, 2019 , p. 44) where the efficacy of experiences their outputs have on the consumers/audiences can be measured by emotions they managed to stir. Although it seems rather difficult to measure intangible assets such as emotions, cultural consumers can easily do it (un)consciously; thus, 
crying when watching a movie, feeling excited due to a certain musical beat, identifying with the main character of a book, or feeling warmth when looking at a certain painting prove the efficacy of experiences provoked by art.

On the other hand, in most people, tourism evokes an immanent association with relaxation time, which is a fertile environment for mood enhancement (Jelinčić \& Senkić, 2019). Today, "a new profile of touristseeking experiences focused on relaxation, discovery, enjoyment, and knowledge" (UNWTO, 2015, p. 35) is noted. So, given that tourists go on holidays in search of pleasurable experiences, and also to escape their daily routine, culture may have an important role in creating longer-lasting experiences by way of supplying cultural tourism. Artworks and the products of creative industries are often used for this purpose (e.g. paintings, films, texts, photos). When "seeded" in the tourism soil, which is inherently associated with "carefree" experiences, it provides solid grounds for an emotional response. The pleasurable experiences a destination offers have a significant impact not only on how tourists feel while in the destination but also help to create their personal attachment with the destination, thus having impacts upon their return. The key, therefore, is to create memorable experiences that a tourist can easily associate with a certain destination. This, eventually, also has a great impact on the destination's competitiveness.

\section{Neuroscientific, Psychological and Business Approach to the Creation of Experiences}

Tourists are often unconscious of how memorable experiences are created by the cultural tourism supply. Stimulation of certain neurons in the human brain result in certain experiences. In order to understand the possibility of intentional experience creation for others, it is first necessary to see how the human brain functions and how it creates an individual experience.

From the neuroscientific point of view, the process of creation begins with a simple thought by way of top-down processing: a process of sending a message to our body. Simply put, our body is intertwined with neural networks which enable us to move in response to our thoughts; the 
nerve impulse travels along the neuron sending a message to another neuron by way of neurotransmitters. Neurotransmitters are "chemical mailmen" which send the message to other nerve cells/body parts. Neutral thoughts (such as I-want-to-raise-a-pen), which are not emotionally charged, enable our bodies to do something (or nothing, depending on the thought) but have no impact on how we feel. Still, neurotransmitters are able to produce moods which may impact our experience, by releasing serotonin or dopamine for example, thus affecting our emotions, movements and sensations. So, if we have an emotionally charged thought (such as I-really-like-this-man), neurotransmitters will chemically impact this "neural travel" by affecting our feelings and eventually actions. In this way, the chemistry of the brain we create on a daily basis by way of thoughts determines how we feel, what we experience and eventually do. Thoughts, however, may be provoked by some environmental stimuli. "The James-Lange theory of emotion states that the immediate, primary cause of an emotion is physical. Bodily changes and physiological processes, which occur as a result of environmental stimuli, evoke certain feelings in the conscious mind" (Coleman \& Snarey, 2001, p. 844). This can be illustrated by the imagined hypothetical situation in which a man is happily enjoying nature when unexpectedly a lion appears (stimulus perceived as a danger). This causes a bodily response (such as increased heartbeat) and stimulates emotions (interpreted as fear). The graphical representation is given in Fig. 1.

According to this theory, experiences can be created by way of external stimuli. However, not all emotions arouse the same bodily response; a distinction can be made between "coarser" (e.g. anger, fear, love, hate, grief, shame) and "subtler" emotions (moral, intellectual and aesthetic feelings). The first type is "coupled with strong bodily reverberations" (James, 1902, p. 241), whereas for the latter type, there is a "thinness and paleness of these feelings" (James, 1958, p. 251), which does not result in the same physiological changes. However, "emotion dissociated from all

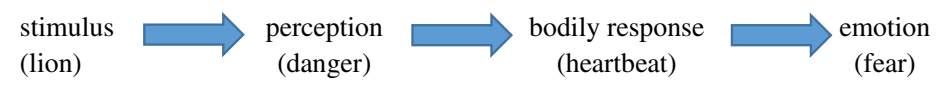

Figure 1: James-Lange theory of emotions. 
bodily feelings is inconceivable" (James, 1958, p. 194); it must be experienced in the body in order to produce an impact on the human psyche (Coleman \& Snarey, 2011, p. 845). This hypothesis provides a solid ground for the creation of experiences in cultural tourism since product/ service providers may actually create external stimuli to possibly trigger emotions in the visitors. As much as it is extremely difficult to figure out the triggers which would incite the emotions in each visitor, since they are mostly individual and could differ from one person to another, some general rules can be applied. Thus, in tourism, which is an activity associated with positive emotions since it represents an escape from the burden of the everyday life, experience creation would probably focus on the stimulation of positive thoughts. This means that the experience we provide should be deprived of negative cues, and instead, the focus should be on the positive ones. Besides these two, Pine and Gilmore (1998, pp. 102-105), have detected three further design principles of experience creation: attributing a theme to each experience, supplying memorabilia as additional experience enhancers and engaging all five senses. Moreover, the theories of experience creation in cultural institutions detect the need of engaging the visitor. Thus, the concept of participatory institutions has been put forward (Simon, 2010; Gesser et al., 2012; Meijer-van Mensch \& van Mensch, 2013) as is the concept of co-creation and participation in the cultural (Prahalad \& Ramaswamy, 2004; Lanier \& Schau, 2007; Walmsley, 2013; Govier, 2018; Leadbeater, 2009) as well as in the tourism sectors (de Bruin and Jelinčić, 2016; Russo and Richards, 2016). The concept of tourist emotional engagement (TEE) (Jelinčić \& Senkić, 2019) is also known. The last is twofold and refers to (1) a general term used to describe various techniques used by cultural institutions in presenting their cultural attractions, stirring the emotions of their visitors, and/or (2) an emotional engagement of tourists toward individual cultural attractions. Summing up the works of different researchers, the key design principles in experience creation are as follows:

1. attributing a theme to each experience,

2. harmonizing impressions with positive cues,

3. eliminating negative ones,

4. supplying memorabilia as additional experience enhancers, 
5. engaging all five senses,

6. stimulating participation and co-creation,

7. stirring emotions in visitors.

Much has been written about most of these design principles, whereas the last one, although logical and self-explanatory, has not been given proper academic attention in relation to tourism. A relevant corpus of research studies on emotions and related concepts such as affect, feelings and moods exist (Shouse, 2005; Cohen, Pham \& Andrade, 2008; Ekman \& Richard, 1994). They are also common in business studies (Pine \& Gilmore, 1998; Sundbo \& Sørensen 2013; Sundbo \& Darmer, 2008). Some academic tourism literature deals with emotions and related concepts (e.g. Buda, 2015) but from a limiting perspective of "its application mainly to customer satisfaction and customer loyalty issues" (Scuttari \& Pechlaner, 2016). Still, there are rare cases of academic papers which focus on the actual tourism experience design by way of emotions (Dias, Correia \& Cascais, 2017). It is probable that a certain attraction will arouse emotions in the visitors if the previous six design principles are applied. In this chapter, special attention is given to the engagement of all five senses since this design principle is especially closely connected with the eventual emotional engagement of the visitor.

\section{Basic Approach to Using Senses in Experience Creation}

Practical toolkits for experience creation usually refer to the importance of the following key elements of (cultural) tourism projects: authentic and local, interactive, visitor-inspired, unique, "best in class", focusing on details, selling the journey and not the destination (Northern Ireland Tourist Board, s.a.). These, however, can be referred to as prerequisites for the actual experience creation which focuses on engaging the five senses, and eventually stirring emotional responses in the visitor.

Most people experience the world through the sense of sight. Human vision is a comparatively stronger sense relative to many other mammals (whereas sense of smell is comparatively weak, for example), and most of us consider it as the primary sense. Still, we do not always perceive the same object equally, which may be due to different causes (such as 
yellowing of the eye lens with age, which results in a different perception of colors; or the viewer's own expectations, which may affect the perception, etc.). It is extremely difficult to know with absolute certainty how a visual experience will be perceived by each individual. In cultural tourism, they may greatly differ and are dependent on the attraction but mainly refer to films, photography, video or different displays. Since it is practically impossible to cover all of them, a general cognitive behavioral approach to the visual experience design is proposed using the think-feel$d o$ activity to draw conclusions on general visual design principles. This approach is a popular marketing tool and entails a brainstorming session which attempts to predict consumers' behavior after the visual stimulation (what they think, feel and do). Thus, the think activity should lead to responses to questions: What do you want your consumers to think about your product? What information do you present to them to support it? What do you want to share with them? When focusing on the feel activity, the following questions may be relied on: What emotions would you like your consumer to feel after seeing your product? Why are these feelings important for your product? The do activity entails the activities you want your consumers to perform after the visual stimulation and should result with a list of such activities. Results of this method form the basis for creating the visual experience.

However, a visual experience is often not complete if it does not include sounds. Music is often used to accompany other senses, and it needs to be harmonized with the product, to create atmosphere and to increase the intensity of the tourists' experience. Apart from music, using sounds can be even more effective. The result will often depend on the technology used, and also on the manner and time of using the sound to arouse an emotional response. Planning the sound experience is a necessary step and involves visual maps which detect relevant moments (e.g. surprise, tension and break, peaks and troughs, drama). Tricks may include "moving the sound around the space and using ultra-lowfrequency sound, which is not necessarily heard but can unsettle people" (Savage, 2016). Often, the so-called binaural sound is used to create the real experience, a method using two microphones for recording, arranged with the intent to create a three-dimensional stereo sound sensation for the listener of actually being in the room with the performers or instruments. 
According to Joel Beckerman, "the most important elements are immersion, contrast, surprise and white space" (Beckerman, 2016). By using immersive sound, audiences are "pulled in", whereas

"contrast is key to creating a soundtrack story. Surprise after surprise raises the heart rate, but there are no effective surprises without contrast. It's like a horror movie soundtrack, where the set-up before the scare is everything. It's tricking the mind into thinking it knows what's coming next and then breaking that expectation. White space, or perceived silence, is more important as attractions become more complex. We simply need a break from the action. The trick isn't to try to create 'silence' but create ambiences that mask sound. These ambiences can be quite specific in terms of their emotional takeaway. They can make you feel a sense of calm, anticipation, magic, wide open space (Beckerman, 2016, p. 45)".

In wanting to create a truly memorable experience, success is highly likely to be achieved by using the sense of smell since it is closely linked with memory and is highly emotive. Research shows that odors are especially effective as reminders of past experience, much more so than cues from other senses (Chu \& Downes, 2002; Maylor, Carter \& Hallett, 2002). This makes it highly appropriate for creating experiences of travel through time and/or space. However, the response to a stimuli of smell does not include a conscious reaction; rather it is likely that the emotional response "is governed by association, something which is borne out by the fact that different people can have completely different perceptions of the same smell" (Psychology and Smell, 2018). The end result is that the audiences stay longer at the attractions and remember the consumed experiences for a longer time.

Smells are usually distributed through the cold-air diffusion technologies. Food-related smells are common in experience creation. However, since different reactions can be expected to a certain smell, it is not easy to choose the right smell so as to create positive associations. Choosing the so-called "billboard scents" is the playing-it-safe approach and is mainly used by big companies. They are marked as "billboard" since they are bold and associate the brand with billboards which are imposed right in the face of the customer. New brands/attractions may want to use the 
background scent strategies to create pleasurable experiences which do not distract. Although research of scents in experience creation has been rather fragmented, there are studies which consider them mostly in relation to different aspects of marketing (Chebat \& Michon, 2003; Bone \& Jantrania, 1992; Mitchell, Kahn \& Knasko, 1995; Morrin \& Ratneshwar, 2000; Spangenberg, Crowley \& Henderson, 1996; Michon, Chebat \& Turley, 2005) but also those in relation to their effect on emotions (Warrenburg, 2005; Sellaro et al., 2014). The latter type of studies detects different impacts of individual scents (cinnamon, lavender, peppermint, mint, lemon, rosemary, etc.) on emotions and moods, which is a useful resource for experience creation.

When it comes to taste, four basic tastes are dominant in Western food research: sweet, bitter, sour and salty. The East, however recognizes umami (savory) as a basic taste (Hadhazy, 2011), and the rules about tastes are not definite. Importance of the taste in experience creation is large but somewhat differs in comparison with other senses: It can hardly be experienced alone, without a sense of smell. Tasting something with a blocked nose results in our inability to recognize the taste. Also, the sense of touch is closely related to taste since we feel the texture of the food in our mouth although it does not necessarily affect the taste itself. Thus, experience creation based on taste should take into account a holistic approach or can otherwise remain ineffective. Not only are the taste and smell of food important, but also its presentation, form, color, consistency, texture, surface and chewing sounds. Preparation technique as well as history related to a served dish are effective storytelling tools in experience creation. Furthermore, experiences may be enhanced by not focusing only on the dish itself but also on the location (a hidden location of the event may be particularly surprising; symbolic locations are also effective such as a beach for the fish menu), people (e.g. individual tours with a chef or sommelier or interaction of guests with them) and type of the event (e.g. hybrid events which combine thematic experience may be effective by combining food, music, film, etc.) where it will be consumed.

Finally, touch may be qualified as the most important sense for experience creation since it directly engages the visitor in participation and consumption of the actual product/service/event. The Confucian aphorism "I see, I forget; I hear, I remember; I do, I understand" proves to be valid 
for the sense of touch, which is in line with previously mentioned theories of co-creation, participation and engagement. Besides, the organ for the sense of touch is the skin, which is the largest organ, so chances for sensory understanding of the environment are greater. By way of skin, humans respond to different stimuli (e.g. pressure, tension, texture, weight, pain, shape, vibrations and contours). Moreover, touch can be experienced by the receptors inside the body (muscles, bones and joints, heart and blood vessels) through the somatosensory system. Hairs and fingernails, though, are deprived of sensory receptors. Although the previously quoted studies advocate the relevance of direct participation in order to leave memorable traces in the visitor, cultural attractions, especially those related to heritage, rarely offer opportunities for tactile interaction. Creation of experiences which include this sense is, therefore, strongly advocated since it leads to active participation and immersion in the experience, which qualify as an escapist experience according to Pine and Gilmore, and which is the most powerful of the four realms of an experience.

"Our five senses — sight, hearing, touch, taste and smell — seem to operate independently, as five distinct modes of perceiving the world. In reality, however, they collaborate closely to enable the mind to better understand its surroundings" (Groeger, 2012). The phenomenon of synesthesia, which comes as a result of merging the sensations, increases the odds for emotional engagement of the visitor. It entails joining together various sensations (smell, taste, hearing, sight and touch) that are in most cases experienced separately. Therefore, if a cultural tourism attraction is to be experienced only through visual sensation, it is less likely to entice a visitor to feel in a certain way, whereas if most or all sensations are joined together, they may create an experience.

\section{Challenges in Experience Creation}

Experience design principles have been proven to work in practice. Still, experiences are always consumed individually and are dependent on the individual perception, triggers, memories, etc. So, an attraction may trigger totally different emotions in different consumers. The biggest challenge for future research, therefore, is to determine how to trigger the same 
reaction in all visitors. Successful results of such a study would greatly support experience creators in achieving desirable outputs with certainty, but, at the same time, would deprive us of creativity in the process of experience creation itself. This process is to be perceived as the experience itself, as a game which involves the creation of new neural networks both for experience creators and experience consumers: new neural networks mean new experiences. Since individual experiences are not always positive, individual experiences, future research may introduce the other previously mentioned design principles which acted as "auxiliary" ones (such as theming, harmonizing impressions with positive cues, eliminating negative ones, etc). They could act as dependent variables for proving the pleasurable experience for all the consumers. Although challenging, such research is perceived as extremely demanding. A research focus on individual emotions resulting from an experience consumption as a prior activity may be performed. This would provide grounds for understanding the causality of different reactions to the same stimulus and only then be considered as the basis for experience creation.

\section{References}

Beckerman, J. (2016). How can Sound be used to Create Incredible Immersive Experiences? Attractions Management 16(4), 45-48.

Bone, P. F. \& Jantrania, S. (1992). Olfaction as a Cue for Product Quality. Marketing Letters 3, 289-296.

Buda, D.-M. (2015). Affective Tourism: Dark Routes in Conflict. Abingdon, Oxon, UK: Routledge.

Chebat, J. C. \& Michon, R. (2003). Impact of Ambient Odors on Mall Shoppers' Emotions, Cognition, and Spending - A Test of Competitive Causal Theories. Journal of Business Research 56, 529-539.

Chu, S. \& Downes, J. J. (2002). Proust Nose Best: Odors are Better Cues of Autobiographical Memory. Memory \& Congnition 30(4), 511-518.

Cohen, J. B., Pham, M. T. \& Andrade, E. D. (2008). The Nature and Role of Affect in Consumer Behavior. In C. P. Haugtvedt, P. M. Herr \& F. R. Kardes (Eds.), Handbook of Consumer Psychology, New York, NY [u.a.]: Erlbaum, pp. 297-348.

Coleman, A. E. \& Snarey J. (2011). James-Lange Theory of Emotion. In: S. Goldstein \& J. A. Naglieri (Eds.), Encyclopedia of Child Behavior and 
Development, Boston, MA: Springer, pp. 844-846. DOI: 10.1007/978-0387-79061-9_3146.

de Bruin, A. \& Jelinčić, D. A. (2016). Toward Extending Creative Tourism: Participatory Experience Tourism. Tourism Review 71(1), 57-66.

Dias, J. A., Correia, A. \& Cascais, T. (2017). Traits in Tourists' Experiences: Senses, Emotions and Memories. In A. Correia, M. Kozak, J. Gnoth \& A. Fyall (Eds.), Co-Creation and Well-Being in Tourism. Tourism on the Verge. Cham: Springer, pp. 179-193.

Ekman, P. \& Richard, J. D. (Eds.), (1994). The Nature of Emotions: Fundamental Questions. Oxford, UK: Oxford University Press.

Gesser, S., Handschin, M., Jannelli, A. \& Lichtensteiger, S. (Eds.), (2012). Das partizipative Museum. Zwischen Teilhabe und User Generated Content. Neue Anforderungen an kulturhistorische Ausstellungen. Bielefeld: transcript Verlag.

Govier, L. (2018, January 17). Leaders in Co-Creation: Why and How Museums could Develop their Co-Creative Practice with the Public, Building on Ideas from the Performing Arts and other Non-Museum Organisations. Retrieved from https://www2.le.ac.uk/departments/museumstudies/rcmg/projects/ leaders-in-co-creation/Louise\%20Govier\%20-\%20Clore\%20Research\%20$\% 20$ Leaders\%20in\%20Co-Creation.pdf.

Groeger, L. (2012). Sensory Cross Talk Helps us Navigate The World. Retrieved from https://www.scientificamerican.com/article/making-sense-world-sveralsenses-at-time/.

Hadhazy, A. (2011). Tip of the Tongue: Humans may Taste at least 6 Flavors. Livescience. Retrieved from https://www.livescience.com/17684-sixth-basictaste.html.

Holbrook, M. B. \& Hirschman, E. C. (1982). The Experiential Aspects of Consumption: Consumer Fantasies, Feelings, and Fun. Journal of Consumer Research 9(2), 132-140. DOI: 10.1086/208906.

James, W. (1958). Talks to Teachers on Psychology. And to Students on some Life's Ideals. New York: W.W. Norton.

James, W. (1902). The Varieties of Religious Experience. New York: Penguin Books.

Jelinčić, D. A. (2011). Kultura kao lijek za propalu industriju. In A. Černelič Krošelj, Ž. Jelavić \& H. Rožman (Eds.), Kulturna dediščina industrijskih panog/Industrijska kulturna baština. 11. Vzporednice med slovensko in hrvaško etnologijo/11. Hrvatsko-slovenske etnološke paralele. Ljubljana: Slovensko etnološko društvo, pp. 58-69. 
Jelinčić, D. A. \& Senkić, M. (2017). Creating a Heritage Tourism Experience: The Power of Senses. Etnološka tribina: Journal of Croatian Ethnological Society 47(40), 109-126. DOI: 10.15378/1848-9540.2017.40.03.

Jelinčić, D. A. \& Senkić, M. (2019). The Value of Experience in Culture and Tourism: The Power of Emotions. In G. Richards \& N. Duxbury (Eds.), A Research Agenda for Creative Tourism. Cheltenham, UK: Edward Elgar Publishing, pp. 41-53.

Jelinčić, D. A., Žuvela, A. \& Polić, M. (2012). Zagreb kao kulturni proizvod: Akcijski plan poticanja razvoja kulturnih/kreativnih industrija u gradu Zagrebu. Zagreb: Institut za međunarodne odnose.

Lanier, C. D. \& Jensen Schau, H. (2007). Culture and Co-Creation: Exploring Consumers' Inspirations and Aspirations for Writing and Posting On-Line Fan Fiction. In R. W. Belk \& J. F. Sherry (Eds.), Consumer Culture Theory (Research in consumer behaviour), Vol. 11. Bingley: Emerald Group Publishing Limited, pp. 321-342.

Leadbeater, Ch. (2009). The Art of With. Manchester: Cornerhouse.

Maylor, E. A., Carter, S. M. \& Hallett, E. L. (2002). Preserved Olfactory Cuing of Autobiographical Memories in Old Age. The Journals of Gerontology. Series B, Psychological Sciences and Social Sciences 57(1), 41-46.

Meijer-van Mensch, L., \& van Mensch, P. (2013). Participative Strategies in Collecting the Present. Introduction. In: L. Meijer-van Mensch \& E. Tietmeyer (Eds.), Participative Strategies in Collecting the Present. Berliner Blätter Heft 63. Berlin: Panama Verlag, pp. 8-14.

Michon, R., Chebat, J. C. \& Turley, L. W. (2005). Mall Atmospherics: The Interaction Effects of the Mall Environment on Shopping Behavior. Journal of Business Research 58, 576-583.

Mitchell, D. J., Kahn, B. E. \& Knasko, S. C. (1995). There's Something in the Air: effects of Congruent or Incongruent Ambient Odor on Consumer Decision Making. Journal of Consumer Research 22(September), 229-238. Morrin, M. \& Ratneshwar, S. (2000). The Effect of Retail Store Environment on Retailer Performance. Journal of Business Research 49, 167-181.

Northern Ireland Tourist Board (s.a.). Creating experiences. A Toolkit for the NI Tourism Industry. <s.1.>: Northern Ireland Tourism Board. Retrieved from https://www.tourismni.com/globalassets/grow-your-business/toolkits-andresources/experiences-guides/creating-experiences-toolkit.pdf.

Pine, B. J. II. \& Gilmore, J. (1998). Welcome to the Experience Economy. Harvard Business Review July-August(1). Retrieved from https://hbr. org/1998/07/welcome-to-the-experience-economy. 
Prahalad, C. K. \& Ramaswamy, V. (2004). Co-creation Experiences: The Next

Practice in Value Creation. Journal of Interactive Marketing 18(3), 5-14.

Russo, A. P. \& Richards, G. (2016). Reinventing the Local in Tourism: Producing,

Consuming and Negotiating Place. Bristol/Tonawanda/North York: Channel

View Publications.

Psychology and Smell, (2018, January 19). Fifth sense. Smell, taste, life.

Retrieved from http://www.fifthsense.org.uk/psychology-and-smell/.

Savage, D. (2016). How can Sound be used to Create Incredible Immersive Experiences? Attractions Management 16(4), 45-48.

Scuttari, A. \& Pechlaner, H. (2016). Emotions in Tourism: From Consumer Behavior to Destination Management . In: D. Fesenmaier \& Z. Xiang (Eds.),

Design Science in Tourism. Tourism on the Verge. Cham: Springer, pp. 41-53. Sellaro, R., van Dijk, W. W., Rossi Paccani, C., Hommel, B. \& Colzato, L. S. (2014). A Question of Scent: Lavender Aroma Promotes Interpersonal Trust. Frontiers in Psychology 5, 1486.

Shouse, E. (2005). Feeling, Emotion, Affect. Media and Culture Journal 8(6).

Retrieved from http://journal.media-culture.org.au/0512/03-shouse.php.

Simon, N. (2010). The Participatory Museum. Santa Cruz, CA: Museum 2.0.

Spangenberg, E. R., Crowley, A. E. \& Henderson, P. W. (1996). Improving the Store Environment: Do Olfactory Cues Affect Evaluations And Behaviors? Journal of Marketing 60(April), 67-60.

Sundbo, J. \& Darmer, P. (2008). Creating Experiences in the Experience Economy. Cheltenham, UK/Northampton, MA, USA: Edward Elgar.

Sundbo, J. \& Sørensen, F. (2013). Introduction to the Experience Economy. In J. Sundbo \& F. Sørensen (Eds.), Handbook on The Experience Economy. Cheltenham, UK/Northampton, MA, USA: Edward Elgar, pp. 1-17.

Toffler, A. (1970). The Future Shock. New York: Random House.

UNWTO (2015), 'Affiliate Members Global Reports, Volume twelve - Cultural Routes and Itineraries', Madrid: UNWTO.

Walmsley, B. (2013). Co-Creating Theatre: Authentic Engagement or InterLegitimation? Cultural Trends 22(2), 108-118.

Warrenburg, S. (2005). Effects of Fragrance on Emotions: Moods and Physiology. Chemical Senses 30(1), 248-249. 